\title{
Insulin Stimulates Amino Acid and Lipid Metabolism in Isolated Fetal Rat Hepatocytes
}

\author{
JOHN D. MILLER, MADHUR K. SINHA, ${ }^{1}$ MARK A. SPERLING, AND SUPRIYA GANGULI \\ Department of Endocrinology, Children's Hospital Medical Center, Cincinnati, Ohio 45229
}

\begin{abstract}
Although fetal hyperinsulinemia is associated with excessive deposition of glycogen in liver, both in vivo and in vitro studies show little effect of insulin on glycogen synthesis from glucose or the activity of the enzyme glycogen synthase in the fetus. To investigate whether lack of insulin effect extends to other fetal metabolic processes, we compared the influence of insulin on amino acid uptake $\left({ }^{14} \mathrm{C}\right.$ - $\alpha$-aminoisobutyric acid) and lipid synthesis $\left[{ }^{14} \mathrm{C}\right.$-acetate) in freshly isolated hepatocytes from 21-day fetal (F) and adult (A) rats. Viability of $F$ and $A$ hepatocytes was documented by trypan blue exclusion (>90\%). In A, insulin stimulated ${ }^{14} \mathrm{C}$ - $\alpha$-aminoisobutyric acid uptake in a dose dependent manner with an apparent $\mathrm{Km}$ at $2 \mathrm{ng} / \mathrm{ml}$ and a $V \max$ at $10 \mathrm{ng} / \mathrm{ml}$. When corrected for cell surface area, $F$ cells responded to insulin in a similar dose response manner, although absolute values per $1 \times 10^{6}$ cells always remained lower. In contrast, whereas $A$ cells demonstrated a typical dose dependent response of ${ }^{14} \mathrm{C}$-acetate incorporation into lipid with a $\mathrm{Km}$ at $5 \mathrm{ng} / \mathrm{ml}$ and $V \max$ at $10 \mathrm{ng} / \mathrm{ml}$ of insulin, $F$ cells remained totally unresponsive when the concentration of acetate was $5 \mathrm{mM}$ or less. However, at higher medium acetate concentrations $(15-30 \mathrm{mM})$ fetal responses were equal to or greater than that of adult, both basally and with insulin. These findings suggest differences in the maturation of insulin-mediated processes in fetal rat hepatocytes; effects on amino acid uptake appear earlier than those on lipid or glycogen synthesis. (Pediatr Res 20: 609-612, 1986)
\end{abstract}

\section{Abbreviations}

$\alpha$-AIB, $\alpha$-aminoisobutyric acid

BSA, bovine serum albumin

Insulin is present in the circulation early in gestation (1) and insulin receptors have been identified in various fetal tissues $(2$, 3 ), but the precise role of insulin in fetal metabolism remains controversial $(3,4)$. Macrosomia occurs with fetal hyperinsulinemia in humans as well as in experimental models such as the fetal rhesus monkey, indicating anabolic effects of insulin in utero $(4,5)$. In the rhesus monkey model, chronic fetal hyperinsulinemia achieving levels of approximately $3500 \mu \mathrm{U} / \mathrm{ml}$, failed to alter the activities of hepatic enzymes that promote glucose

Received September 9, 1985; accepted February 18, 1986

Address for correspondence and reprints, John D. Miller, M.D., Department of Pediatrics, City of Hope National Medical Center, 1500 East Duarte Road, Duarte, CA 91010

This work was supported in part by grants from the Children's Hospital Research Foundation, the Juvenile Diabetes Foundation, and by USPHS-NIH Grants HD 12613 and HD 11725 .

Current address Department of Medicine, East Carolina University, Greenville, NC 27834. utilization, glycolysis, or glycogen synthesis (4). The activities of lipogenic enzymes, however, were enhanced in this model in which selective organomegaly was evident $(4,6)$. These findings suggest that the anabolic actions of insulin in utero are mediated more by effects on lipid and/or protein than on carbohydrate metabolism.

In support of these findings, we previously reported that insulin-mediated incorporation of glucose into glycogen and insulin-stimulated glycogen synthase activity were not demonstrable in isolated fetal rat hepatocytes possessing an increased number of insulin receptors relative to adult rat liver; adult rat hepatocytes responded appropriately (3). The present studies were undertaken to examine the effects of insulin on two other established insulin-mediated actions, namely, $\alpha$-AIB uptake and acetate incorporation into lipids, in isolated fetal and adult rat hepatocytes.

\section{MATERIALS AND METHODS}

Monocomponent porcine insulin was from Eli Lilly and Company (Indianapolis, IN). Collagenase and bacitracin were purchased from Sigma Chemical Company (St. Louis, MO); RPMI1640 medium from Gibco (Grand Island, NY); BSA, fraction V, from Miles Laboratories (Elkhart, IN); and ${ }^{14} \mathrm{C}-\alpha$-AIB $(40-60$ $\mathrm{mCi} / \mathrm{mmol})$ and ${ }^{14} \mathrm{C}$-acetic acid-Na salt $(45-60 \mathrm{mCi} / \mathrm{mmol})$ from New England Nuclear Corporation (Boston, MA). All other chemicals were purchased from Sigma. Aqueous scintillate was obtained from Amersham Corporation (Arlington Heights, IL).

\section{ISOLATION OF HEPATOCYTES}

Adult. Fresh hepatocytes were isolated from male SpragueDawley rats of $150-200 \mathrm{~g}$ body weight, according to the modified method of Berry and Friend (7) as previously described (3).

Fetus. Fetuses were removed by caesarian section of pregnant, Sprague-Dawley rats at 21 day gestation (term $=21-22$ days). The fetal livers from six or more pregnancies were pooled, placed in chilled, calcium-free KRB buffer and gently minced. The minced livers were then digested for $10 \mathrm{~min}$ at $37^{\circ} \mathrm{C}$ under $95 \%$ $\mathrm{O}_{2}-5 \% \mathrm{CO}_{2}$ atmosphere with buffer containing $1.5 \mathrm{mg} / \mathrm{ml}$ of collagenase. The subsequent preparation of fetal rat hepatocytes and their separation from hematopoietic or other liver cell types was as previously described (3). The viability of both fetal and adult rat hepatocytes was assessed by trypan blue exclusion.

\section{EXPERIMENTAL DESIGN}

Fetal and adult rat hepatocytes were preincubated for $30 \mathrm{~min}$ at $37^{\circ} \mathrm{C}$ under $\mathrm{O}_{2}-\mathrm{CO}_{2}$ atmosphere at a concentration of $1-2 \times$ $10^{6}$ cells $/ \mathrm{ml}$ in $3 \%$ BSA-RPMI medium to permit recovery of the cells from collagenase treatment. The cells were then resuspended in assay medium, which consisted of RPMI containing $11.2 \mathrm{mM}$ glucose, bacitracin $(0.5 \mathrm{mg} / \mathrm{ml})$, and $2 \%$ BSA, $\mathrm{pH} 7.4$. Separate experiments were then performed for ${ }^{14} \mathrm{C} \alpha$-AIB uptake and ${ }^{14} \mathrm{C}$-acetate incorporation into lipid. 


\section{$\alpha$-AIB UPTAKE}

Measurement of AIB uptake was performed by the method of Le Cam and Freychet (8) using freshly isolated hepatocytes incubated in assay medium containing insulin at concentrations of 0 to $100 \mathrm{ng} / \mathrm{ml}$ for $2 \mathrm{~h}$ at $37^{\circ} \mathrm{C}$. Following this preincubation, ${ }^{14} \mathrm{C}$-AIB $(0.1 \mathrm{mM}, 1.4 \mathrm{mCi} / \mathrm{mmol})$ was added for another 20 $\min$. The reaction was then terminated by washing with an icecold phosphate-buffered saline solution, $\mathrm{pH}$ 7.4. The cells were precipitated by centrifugation and then hydrolyzed with $0.1 \mathrm{~N}$ $\mathrm{NaOH}$ at $100^{\circ} \mathrm{C}$ for 30 min; samples were neutralized with $\mathrm{HCl}$ and residual radioactivity counted in a liquid scintillation counter with automatic quench correction. Nonspecific trapping in the extracellular volume was initially assessed via ${ }^{14} \mathrm{C}$-inulin and found to be insignificant. To account further for nonspecific extracellular trapping of ${ }^{14} \mathrm{C}-\alpha$-AIB and its contribution to final counts, one set of flasks containing hepatocytes and ${ }^{14} \mathrm{C}-\alpha$-AIB was kept on ice and processed in an identical manner. This background value was subtracted from the mean of each triplicate value; results are expressed as percent change above basal of ${ }^{14} \mathrm{C}$ - $\alpha$-AIB in $\mathrm{pmol} / 1 \times 10^{6}$ cells $/ 20 \mathrm{~min}$. The influence of varying the insulin concentration from $0-100 \mathrm{ng} / \mathrm{ml}$ was compared in the fetal and adult rat hepatocytes. On separate days, five fetal and five adult hepatocyte preparations were obtained and the experiments completed as described above.

\section{ACETATE INCORPORATION}

Total lipid synthesis was measured in freshly isolated hepatocytes ( $n=5$ for both fetal and adult cells) following a 1-h incubation with insulin $0-100 \mathrm{ng} / \mathrm{ml}$ using a method described by Caro and Amatruda (9). The sodium salt of ${ }^{14} \mathrm{C}$ acetic acid $(0.1 \mathrm{mCi} / \mathrm{mmol})$ was added to an Erlenmeyer flask containing $1-2 \times 10^{6}$ cells $/ \mathrm{ml}$ prepared and suspended as described above. After a further $20 \mathrm{~min}$ of incubation, triplicate aliquots were removed for measurement of the incorporation rate of ${ }^{14} \mathrm{C}$ acetate into total lipids, determined by double extraction with chloroform, methanol, and water according to the method of Bligh and Dyer (10).

Two protocols were followed. In the first, acetate incorporation into lipid was determined at a fixed acetate concentration of 5 $\mathrm{mM}$ while varying the insulin concentration between 0 and 100 $\mathrm{ng} / \mathrm{ml}$. In the second, the acetate concentration was varied between 2 and $30 \mathrm{mM}$, and at each concentration the effects of insulin, $100 \mathrm{ng} / \mathrm{ml}$, were determined. Results are expressed as percent increase above basal.

\section{STATISTICAL ANALYSIS}

Student's $t$ test for paired and nonpaired data was used to assess statistical significance for changes within and between groups. All data are presented as mean \pm SEM.

Correction for cell size. Fetal hepatocytes are smaller than cells isolated from adult liver. To correct for potential differences in metabolic response between adult and fetal cells as a result of size, we calculated surface area from microscopic measurement of cell diameter of a representative number of cells; this calculation assumes that the cells are perfect spheres.

\section{RESULTS}

Viability. As assessed by trypan blue exclusion, viability of fetal and adult hepatocyes was more than $90 \%$.

Effect of insulin on AIB uptake. In adult hepatocytes, insulin stimulated AIB uptake in a dose-dependent manner with an apparent $\mathrm{Km}$ at $2 \mathrm{ng} / \mathrm{ml}$ and a $\mathrm{Vmax}$ at $10 \mathrm{ng} / \mathrm{ml}$. Some response in a dose-related manner was also present in the fetal hepatocytes (Fig. 1, top panel). The surface area of fetal cells was approximately 0.4 that of the adult cells. The response in fetal hepatocytes becomes more apparent when corrected for this cell surface area difference. With this correction, insulin stimulated AIB uptake in the fetal cells in a more pronounced dose response manner similar to that obtained in the adult cells, although absolute values per $1 \times 10^{6}$ cells were always lower in the fetal hepatocytes (Fig. 1, bottom panel).

Effect of insulin on acetate incorporation into lipid. Figure 2 demonstrates the effect of insulin on the incorporation of labeled acetate into lipid in both adult and fetal hepatocytes. With the acetate concentration fixed at $5 \mathrm{mM}$, the adult cells demonstrate a typical dose-dependent response with a $\mathrm{Km}$ of $5 \mathrm{ng} / \mathrm{ml}$ and a Vmax of approximately $10 \mathrm{ng} / \mathrm{ml}$. Fetal cells, however, showed no augmentation. To determine if varying the acetate concentration in the medium affects its incorporation rate, we examined the influence of insulin on incorporation rates of acetate at 2,5 , 15 , and $30 \mathrm{mM}$.

In the adult hepatocytes, maximal rates of acetate incorporation into lipid were achieved at concentrations of $5 \mathrm{mM}$; no further augmentation occurred when the concentration of acetate was increased to $30 \mathrm{mM}$. At each concentration of acetate tested,
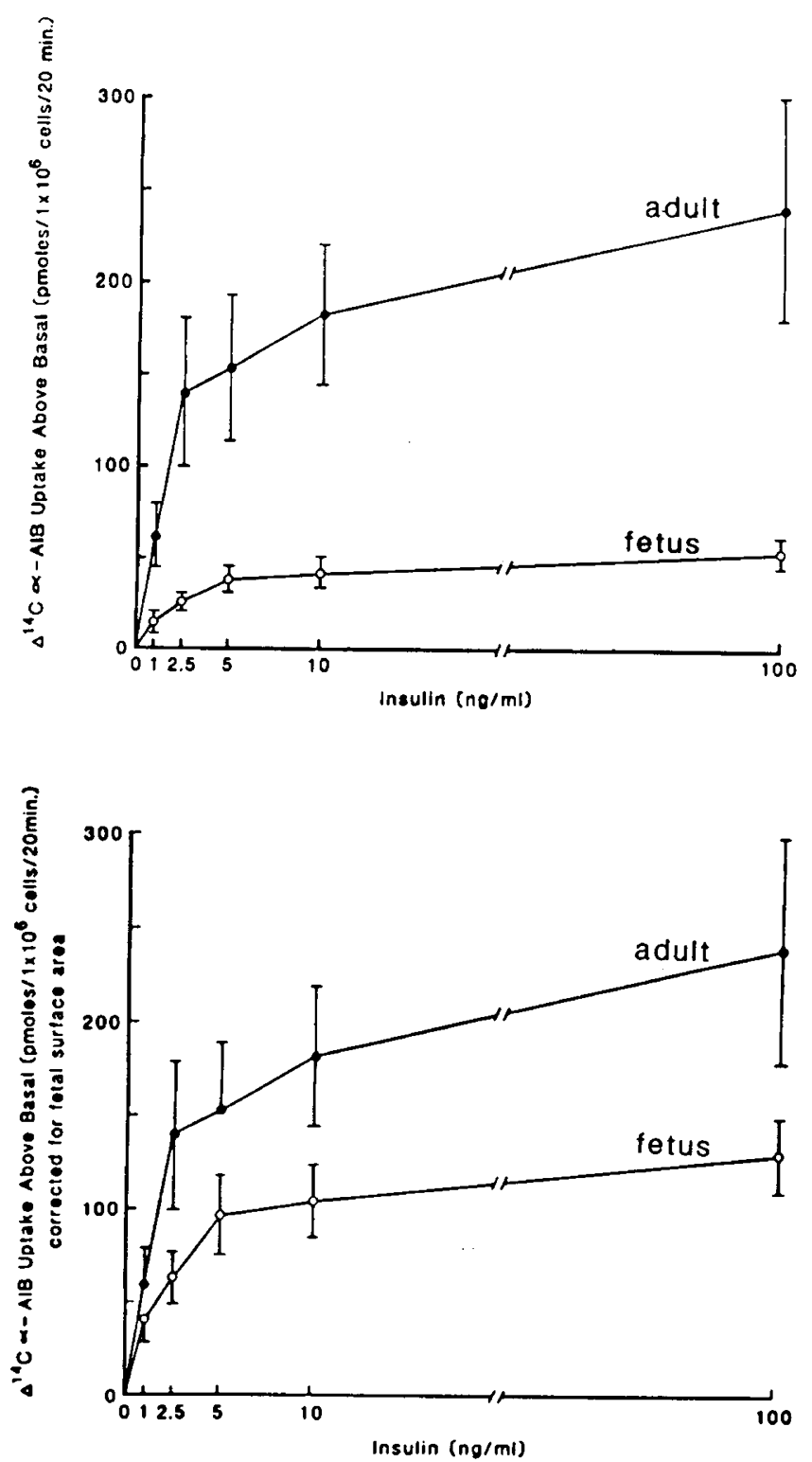

Fig. 1. Effect of insulin on ${ }^{14} \mathrm{C}-\alpha \mathrm{AIB}$ uptake in isolated fetal and adult rat hepatocytes. Results are expressed as mean \pm SEM increment above basal, in pmol $/ 1 \times 10^{6}$ cells $/ 20$-min incubation. Absolute values are shown in the top panel. In the bottom panel, the response in fetal cells has been corrected for cell surface area as detailed in the text. 
however, insulin further augmented the response above that obtained in the absence of insulin. The increment above basal is statistically significant and consistently on the order of $25 \%$ (Fig. 3 ). In contrast, the response in the fetal cells was markedly dependent on the concentration of acetate in the incubation medium. Thus, acetate incorporation into lipid increased progressively with increasing acetate concentrations between 2-30 $\mathrm{mM}$. Although insulin at $100 \mathrm{ng} / \mathrm{ml}$ had no effect at acetate concentrations of 2,5 , and $15 \mathrm{mM}$, it significantly augmented the incorporation at $30 \mathrm{mM}$ acetate to approximately $50 \%$ above the basal level (Fig. 3).

The differences in response to insulin between adult and fetal cells is more clearly illustrated in Figure 4. There was an approximately $25 \%$ increase above basal in acetate incorporation into lipid in the adult cells at all acetate concentrations tested. In contrast, there was an approximately $50 \%$ increase above basal in the fetal cells significant only at $30 \mathrm{mM}$. In separate experiments in fetal cells, there also was an approximate $50 \%$ augmentation with insulin at $10 \mathrm{mM}$ acetate (data not shown).

\section{DISCUSSION}

The present study was undertaken to examine if the previously observed failure of insulin to stimulate glucose incorporation into glycogen and glycogen synthase activity in isolated fetal rat

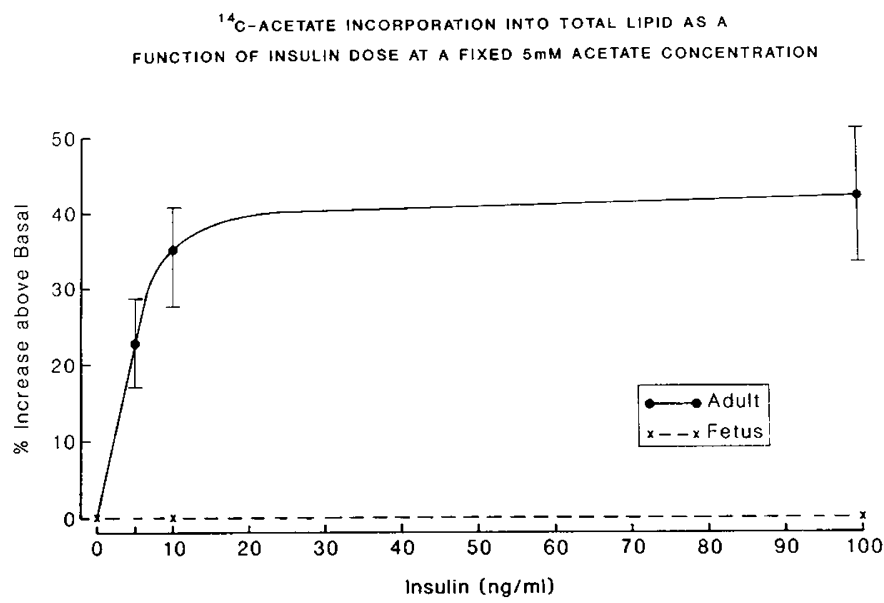

Fig. 2. Effect of insulin on ${ }^{14} \mathrm{C}$-acetate incorporation into lipid by isolated fetal and adult rat hepatocytes. Results are plotted as mean \pm SEM of the percent increase above basal at a fixed medium acetate concentration of $5 \mathrm{mM}$ hepatocytes (3) extends to other known insulin-mediated actions. In contrast to its apparent lack of effect on fetal glycogen metabolism, insulin was capable of augmenting amino acid uptake and acetate incorporation into lipid. These findings have several important implications.

First, the augmentation of $\alpha$-AIB uptake and of acetate incorporation into lipid by insulin indicates that these fetal cells were viable and responsive to insulin. Hence, our previously reported failure to demonstrate an effect of insulin on glycogen synthesis cannot be solely ascribed to cell damage during their isolation (3), especially since the lack of potency of insulin on glycogen synthesis has now been confirmed in cultured fetal rat hepatocytes (11). Furthermore, these in vitro findings are consistent with in vivo studies of the chronically hyperinsulinemic fetal monkey in which there also was no effect on the activity of hepatic glycogen synthase $(4,6)$. Since glucose and galactose are readily assimilated into glycogen both in vivo and in vitro using isolated fetal hepatocytes or perfused fetal liver, neither system demonstrating potent stimulation by insulin $(3,12,13)$, it ap-

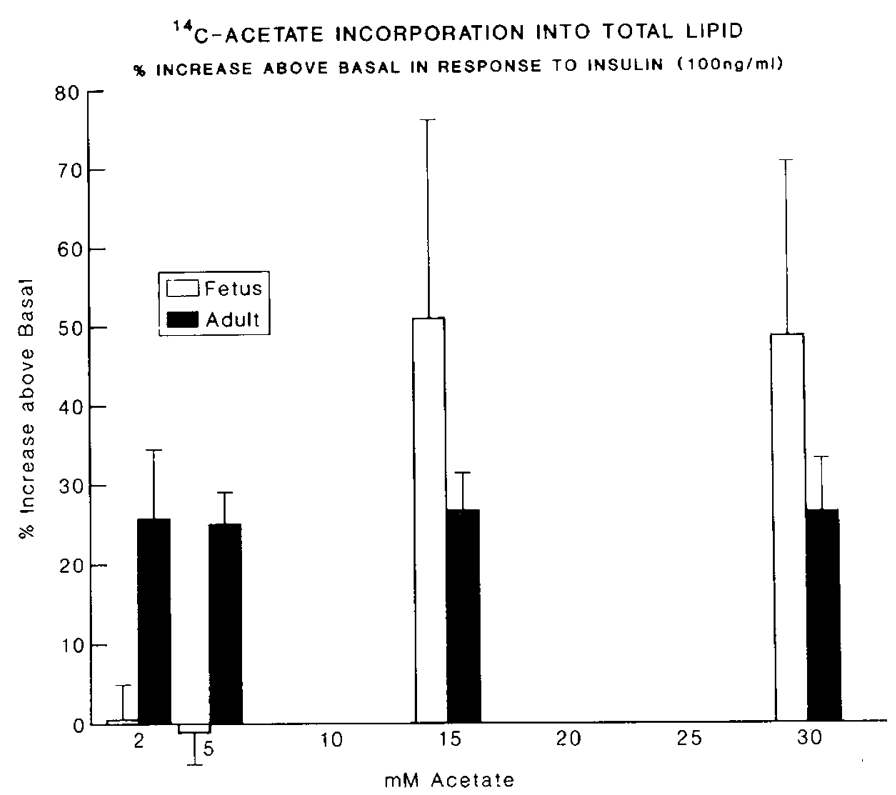

Fig. 4. Effect of insulin, $100 \mathrm{ng} / \mathrm{ml}$, on stimulation of acetate incorporation into lipid by isolated fetal and adult rat hepatocytes at varying acetate concentrations in the incubation medium. Results are expressed as mean \pm SEM of the percent increase over basal (no insulin).

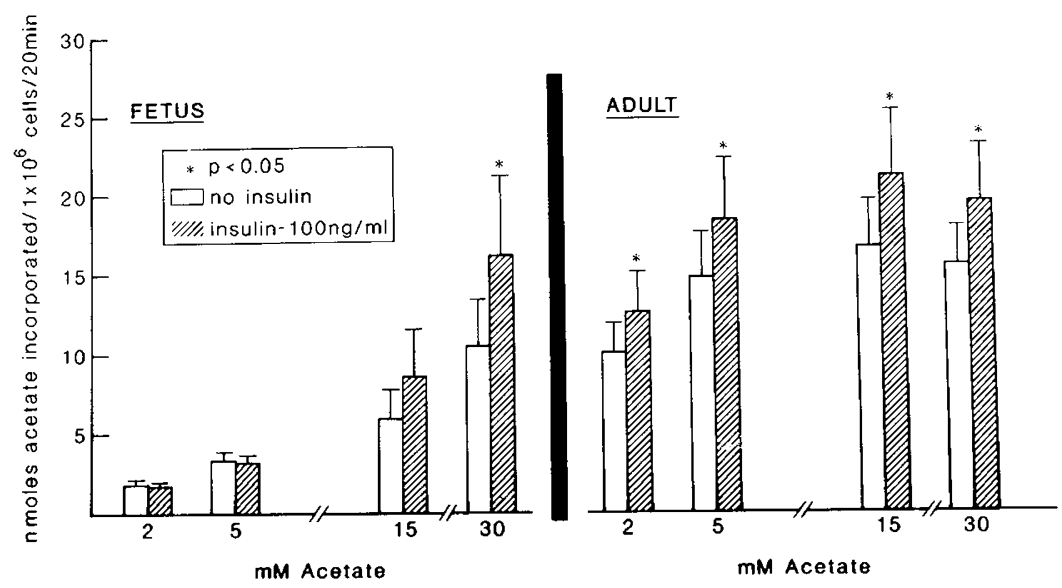

Fig. 3. Effect of varying the medium acetate concentration on basal and insulin-stimulated acetate incorporation into lipid by isolated fetal and adult rat hepatocytes. Results are expressed as mean $\pm \mathrm{SEM}$ of nmol acetate incorporated $/ 1 \times 10^{6}$ cells $/ 20$-min incubation. ${ }^{*} p<0.05$ in comparison to no insulin. 
pears that insulin may be less important for glycogen than for amino acid metabolism.

Second, the augmentation by insulin of $\alpha$-AIB uptake in fetal rat hepatocytes is consistent with findings in the developing fetal rat heart. In this system, ${ }^{14} \mathrm{C}-\alpha$-AIB uptake was demonstrable from the 16th gestational day onward and insulin increased this process at all subsequent gestational ages studied (14). A dissociation of insulin's effects on protein synthesis independent of glucose and energy metabolism has also been reported in adult rat heart (15). Thus, it is possible that fetal insulin may be more important for amino acid than glucose metabolism.

Third, the augmentation of acetate incorporation into lipid by fetal rat hepatocytes suggests an acute effect of insulin in enhancing the activity of lipogenic enzymes. There were, however, differences between the fetal and adult responses with respect to acetate incorporation into lipid. Whereas the adult cells were at maximal responsiveness at $5 \mathrm{mM}$ acetate, the response in fetal cells was more dependent on substrate concentration. In fact, in the absence of insulin, an acetate concentration of 15 to $30 \mathrm{mM}$ was required in the fetal cells to attain the incorporation observed with $2 \mathrm{mM}$ in adult cells. Furthermore, while adult cells were responsive to insulin at all acetate concentrations, the fetal cells demonstrated insulin sensitivity only at the higher substrate concentrations. These relative differences persist even when corrected for the difference in surface area of the fetal cells, although when this correction is made, the response of the fetal cells at 15 $\mathrm{mM}$ is equivalent to that of adult cells.

These differences may reflect decreased activity of the enzymes involved in lipid synthesis, i.e. incomplete enzyme maturation in the fetal cells at the gestational age tested (16). Alternatively, there may be a decreased intracellular entry of acetate from the medium into fetal cells. Our results do not distinguish between these possibilities. We did not measure the intracellular concentration of acetate or acetyl-CoA and therefore can only compare the responses to defined medium concentrations. Furthermore, the substrate concentrations in vivo of the 21-day fetal rat are not known. However, the greater dependance on substrate concentration is similar to that previously observed for glucose incorporation into glycogen (3). Enhanced activity of enzymes involved in lipid synthesis, such as fatty acid synthase and citrate cleavage, was demonstrated in the liver of the chronically hyperinsulinemic fetal rhesus monkey $(4,6)$. These findings are not directly comparable to ours since they involved a different species, at a different maturational state, and with considerably longer exposure to insulin that may have permitted enzyme induction via de novo protein synthesis $(4,6)$. In contrast, in our in vitro system, cells were exposed to insulin briefly, suggesting that augmented incorporation of acetate into lipid was due to activation of existing enzymes. In the fetal cells this enhancement required a substrate concentration that may be unphysiological. Further studies will be required to determine the reason for this high substrate requirement in order to demonstrate an effect of insulin in fetal hepatocytes.

In summary, amino acid uptake and lipid synthesis are responsive to insulin in fetal rat hepatocytes but quantatively less so than in adult cells. The acute effects of insulin on acetate incorporation are substrate concentration dependent in the fetus. Although not directly comparable, these in vitro findings in rat hepatocytes are consistent with several observations concerning the effects of chronic hyperinsulinemia in the fetal rhesus monkey that suggest that insulin affects protein and lipid synthesis in the fetus.

\section{REFERENCES}

1. Sperling MA 1980 Carbohydrate metabolism: Insulin, głucagon and somatostatin. In: Tulchinsky D, Ryan K (eds) Maternal-Fetal Endocrinology. WB Saunders Co, Philadelphia, pp 333-354

2. Sperling MA, Ganguli S 1983 Pre- and postnatal development of insulin and glucagon receptors: Potential role in energy storage and utilization. J Pediat Gastroenterol Nut 2(suppl):546-551

3. Sinha MK, Miller JD, Sperling MA, Suchy FJ, Ganguli S 1984 Possible dissociation between insulin binding and insulin action in isolated fetal rat hepatocytes. Diabetes 33:864-871

4. McCormick KL, Susa JB, Widness JA, Singer DB, Adamson K, Schwartz R 1979 Chronic hyperinsulinemia in the fetal rhesus monkey: effects on hepatic enzymes active in lipogenesis and carbohydrate metabolism. Diabetes 28:1064-1068

5. Susa JB, Neave C, Sehgat P, Singer DB, Zeller WP, Schwartz R 1984 Chronic hyperinsulinemia in the fetal rhesus monkey: effects of physiologic hyperinsulinemia on fetal growth and composition. Diabetes 33:656-660

6. Susa JB, Gruppuso PA, Widness JA, Domenech M, Clemons GK, Sehgal P, Schwartz R 1984 Chronic hyperinsulinemia in the fetal rhesus monkey: Effects of physiologic hyperinsulinemia on fetal substrates, hormones, and hepatic enzymes. Am J Obstet Gynecol 150:415-420

7. Berry MD, Friend DS 1969 High-yield preparation of isolated rat liver parenchymal cells. J Cell Biol 43:506-519

8. Le Cam A, Freychet P 1978 Effect of insulin on amino acid transport in isolated rat hepatocytes. Diabetologia 15:117-123

9. Caro JF, Amatruda JM 1981 Evidence for modulation of insulin action and degradation independently of insulin binding. Am J Physiol 240 (Endocrino Metab 3):E325-E332

10. Bligh EG, Dyer WJ 1959 A rapid method of total lipid extraction and purification. Can J Bioch Physiol 37:911-915

11. Freemark M, D'Ercole AJ, Handwerger S.1985 Somatomedin-C stimulates glycogen synthesis in fetal rat hepatocytes. Endocrinology 116:2578-2582

12. Kliegman RM, Miettinen EL, Morton S 1983 Potential role of galactokinase in neonatal carbohydrate assimilation. Science 220:302-304

13. Adam PAJ, Keromaki M, Rahila EL, Schwartz AL 1972 Autoregulation of glucose production by isolated perfused human fetal liver. Pediatr Res 6:396

14. Clark CM Jr 1971 The stimulation by insulin of amino acid uptake and protein synthesis in the isolated fetal rat heart. Biol Neonate 19:379-388

15. Flaim KE, Kochel PJ, Kira Y, Kobayashi K, Fossel ET, Jefferson IS, Morgan HE 1983 Insulin effects on protein synthesis are independant of glucose and energy metabolism. Am J Physiol 245:C133-C143

16. Greengard O 1977 Enzymic differentiation of human liver: Comparison with the rat model. Pediatr Res 11:669-676 